\title{
「植物の代謝系理解」の再構築 \#
}

\author{
吉 川 博 道* \\ 福岡農業高校専攻科
}

(平成 23 年 2 月 21 日受理)

Keywords: glycolysis, TCA cycle, photosynthetic excess production, secondary metabolism, active oxygen quenching, oxygen quenching.

\section{著論}

代謝系に関する問題は, 一般的には科学の問題として認 識されているが，代謝系をどのように描くかという過程は 極めて恣意的であり，系を構築する人の思想に依存する. つまり, どの物質を系の出発物質とし, どの物質を経由し, ごの物質を最終物質とするかは，この系を構想した人の世 界観や意識に依存する。では現実の代謝系が，どのような 視点から構築されたのかという観点から種々の代謝系をみ ると，ほぼすべての系が従属栄養生物の視点から構築され ている．以下では，解糖系とこれに続く TCA 回路を例に， 系構築の恣意性について論じる. その後, 独立栄養生物の 視点から，植物の二次代謝の存在意義について総合的に考 察するとともに, 将来の農薬開発の方向に触れることにす る.

\section{1. 解糖系と TCA 回路についての考察}

解糖というカテゴリーに分類されるいくつかの系がある. Glucose 2 分子のピルビン酸へと分解しながら, 通常は ATP と $\mathrm{NADH}_{2}^{+}$を生産するプロセスで, Fig. 1 に示す 2 つの 系が代表的なものであろう。1つは，最もよく知られ中心 経路と屯称されるエムデンーマイヤーホフ経路 (EM 経路) で, glucose 1 分子あたりそれぞれ 2 分子の ATP と $\mathrm{NADH}_{2}^{+}$ が生成する。一方，エントナーードウドロフ経路（ED 経 路）では， 6 炭糖段階でのリン酸化が 1 度しか起こらず，生 産される ATP は 1 分子である ${ }^{1)}$. ED 経路のバイパスで 6 炭 糖段階でのリン酸化を経由せずに 3 炭糖への解裂を起こす ピロ解糖系においては, 正味の ATP 生産は起こらない2).

\# 農薬バイオフロンティアシンポジウム（平成 22 年 8 月 27 日, 於：九州大学）をとりまとめた解説

* 福岡市東区美和台 5-23-12

E-mail: abscience_aa@yahoo.co.jp CPesticide Science Society of Japan
ペントースリン酸経路も解糖を行う系として扱われること があるが，この系では ATP 生産は起こらず $\mathrm{NADH}_{2}^{+}$生産系 する系として意義づけられる場合が多い. さて，この解糖 という系において, 出発物質を glucose, 終点をピルビン酸 としたのは何故であろうか？ Embden や Meyerhofをはじ めとする多くの人々の研究によって 1930 年代中頃までに解 糖系の原型が成立していたわけだが, 系の出発物質に関し ては彼らも迷ったのではないだろうか ${ }^{3)}$. その迷いがグリ コーゲンから glucose への変換系および glycogen から G-1-P を通って G-6-Pへと導く系として代謝マップに残っている ように思われる（以下私見だが，疑問は残る。初めて出現 した生物が従属栄養生物であったとしても, 出現時に利用 可能な量の glucose が前生物的に蓄積していたとは思えな い.メタン細菌などが糖新生側にしか働かない EM 経路を もち glycogen を生合成していることを考え合わせると, glucose を出発物質と認めることはなかなか難しいのではない か $^{4)}$ ). さらに, 彼らは何故解糖系をピルビン酸で止めたの であろうか. 当時, 解糖が起こった際に乳酸が生成するこ とは知られていたし, 一部の乳酸が glycogen へ再合成され ることも知られていた。しかし乳酸を終点としたのでは， 系は乳酸発酵になってしまう。彼らはピルビン酸から連な る酸化的代謝系の存在を考え, とりあえず明らかになった 系の最後尾にあったピルビン酸を終点にしたと思われる. その仮定を満たす化合物「Acetyl CoA」の発見は, 1945 年 F. A. Lipmann によって達成される ${ }^{5)}$.ここで解糖系と TCA 回路の連結が完成したわけだが，現在でもピルビン酸から Acetyl CoA への変換反応はどちらの系にも属さない. 研究 の歴史的経緯を無視できるならば, 解糖系の最終物質を Acetyl CoA にした方が, TCA 回路との接続が理解しやすい. 代謝系構築段階での恣意性の存在を示している例であろう. さて, 解糖の産物であるピルビン酸はミトコンドリア内で 酸化的に脱炭酸を受け Acetyl CoA に変換された後, オギザ ロ酢酸とのクライゼン縮合を経て TCA 回路に導入される. 


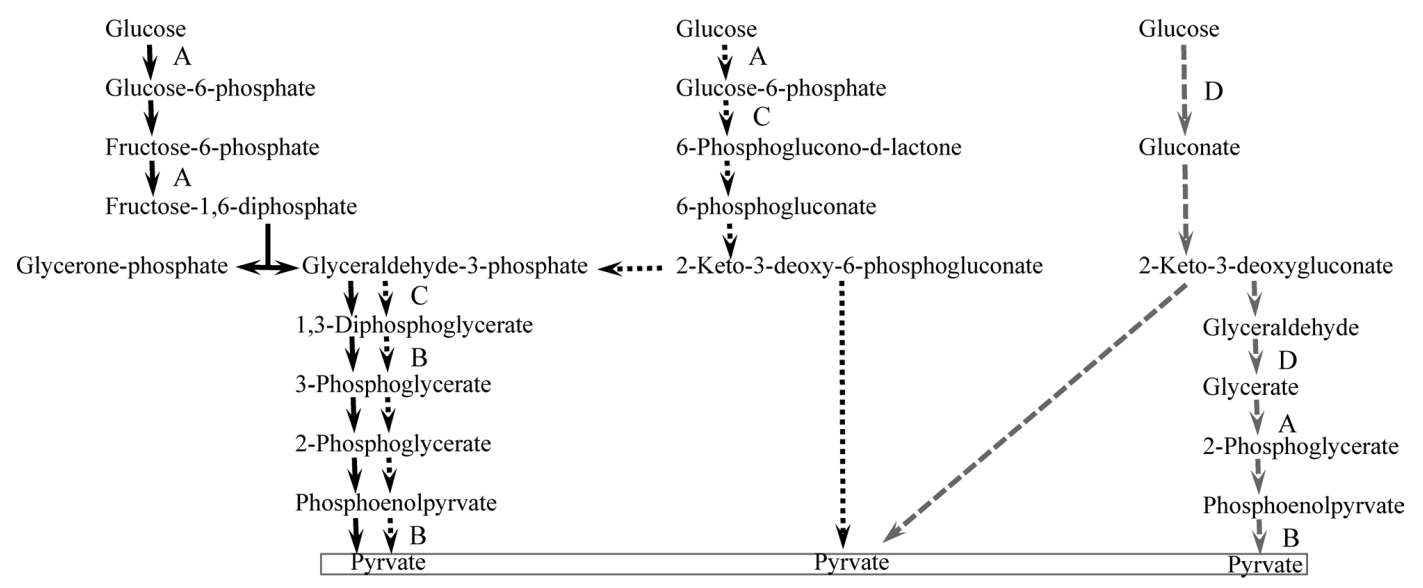

A: ATP consuming process B: ATP producing process $\mathrm{C}$ : $\mathrm{NAD}(\mathrm{P}) \mathrm{H}$ producing process $\mathrm{D}: \mathrm{Fd}_{\text {red }}$ producing process

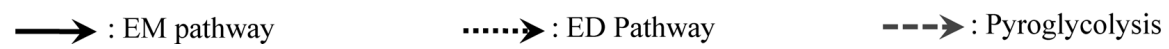

Fig. 1. Emden-Meyerhoff pathway, Entner-Dordorof pathway and pyroglycolysis.

この回路では基質レベルでの酸化が起こり，1 分子のアセ チル $\mathrm{CoA}$ から 3 分子の $\mathrm{NADH}_{2}^{+}, 1$ 分子の $\mathrm{FADH}_{2}$ と 1 分子 の GTP が生産される. TCA 回路で生産された $\mathrm{NADH}_{2}^{+}$と $\mathrm{FADH}_{2}$ は，電子伝達系を通って酸化を受け，それぞれ 3 分 子と 2 分子の ATP を生産する. 多くの場合, 「生物は嫌気 的には 1 分子の glucose から 2 分子の ATP しか合成できな いが，好気生物は解糖系の産物であるピルビン酸を TCA 回 路, 電子伝達系で酸化して 38 分子の ATP を生産できる」
と, TCA 回路と電子伝達系をまとめて好気的エネルギー産 生系として記述される.ところが, TCA 回路を左回りに動 かして $\mathrm{CO}_{2}$ の固定を行っている細菌群が存在する. 彼らの もつ逆転する TCA 回路は還元的カルボン酸サイクルと呼ば れる ${ }^{6)}$. さらに, Fig. 2 に示すように不完全な TCA 回路を 持つ細菌が知られている7). 前者はオギザロ酢酸から左回 りに2-オキソグルタル酸まで, 後者はオギザロ酢酸から右 回りに2-オキソグルタル酸までの代謝系をもつ。では TCA

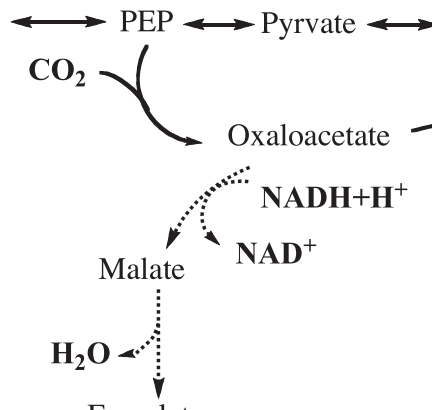

Fumalate

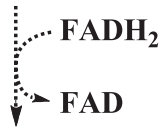

Succinate

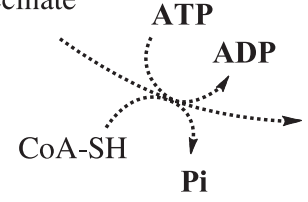

Citrate

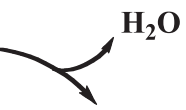

cis-Aconitate<smiles>CCCO</smiles>

iso-Citrate

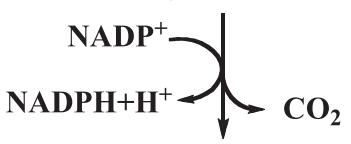

2-Oxoglutarate

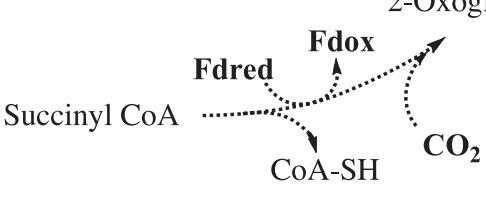

Methanosarcina barkeri, Methanosaeta concilii Methanobacterium thermoautotrophicum

Fig. 2. Imperfect TCA cycle in Methanosarcina barkeri, Methanosaeta concilii and Methanobacterium thermoautotrophicum. 


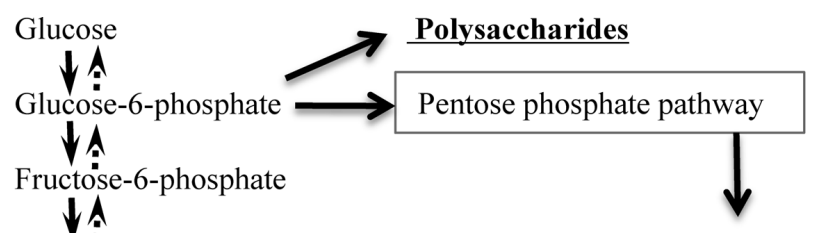

Fructose-1,6-diphosphate Erythrose-4-phosphate Glycerone-phosphate

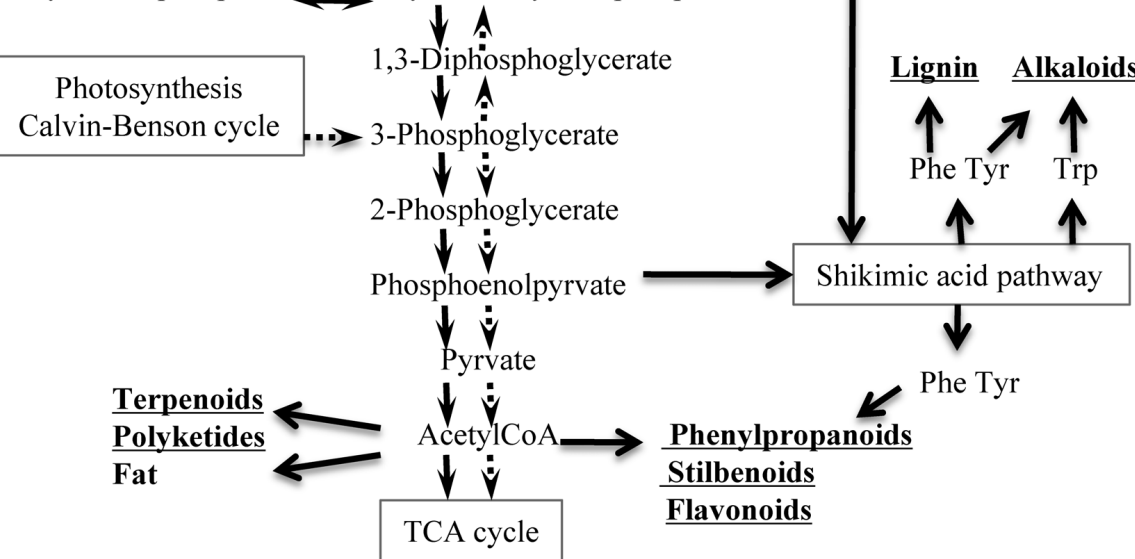

Fig. 3. Directions of metabolic flow in central pathway in animal and in plant, and the massive synthetic processes of secondary metabolites.

回路の持つ意義とは何か？ 電子伝達系と連動する ATP 生 産をもって TCA 回路の持つ意義とはいえない。左回りの $\mathrm{TCA}$ サイクルは $\mathrm{CO}_{2}$ 固定の意義が大きかったであろう。ま た，不完全な TCA 回路を含めて，TCA 回路は糖代謝とア ミノ酸代謝，核酸代謝，ポルフィリン代謝などをつなぐ物 質供給系としての意義が大きいに違いない，歴史的に見れ ば，シアノバクテリアの光合成による $\mathrm{O}_{2}$ の増加に伴い, ミ トコンドリアの起源となった微生物体内で TCA 回路は回転 方向を変え， $\mathrm{O}_{2}$ を使用して ATP を生産する酸化的リン酸化 系とドッキングしたと考えるのが妥当であろう。では解糖 系と TCA 回路は，何故前述したように一連の ATP 生産系 として説明されるのか？これは，ヒトが従属栄養生物と しての世界観に基づいて判断をしていることが原因であろ う。植物は光合成を行う。植物にとっての EM 経路では, カルビンサイクルの生産物である 3-ホスホグリセリン酸か ら分岐し, 糖新生への流れと Acetyl CoA への流れが優勢で あることは明らかである (Fig. 3). また，光化学系での ATP 生産が過剩であることを考えれば，植物での TCA 回路の役 割は，ATP 生産ではなく糖代謝とアミノ酸代謝，核酸代謝， ポルフィリン代謝などをつなぐ系としての意味が大きいに 違いない。このように，代謝系の意義が，独立栄養生物で あるか従属栄養生物であるかに依存すると同時に，地球環 境の変動に伴って変化してきた可能性を考慮し，植物の二 次代謝系を解釈してみたい.

\section{2. 植物の二次代謝系を考える一 Hidden Burden Hypothesis}

一般論であるが，代謝は大まかに異化（catabolism）と同 化（anabolism）に分類される. 異化とは有機物を分解して エネルギーを獲得する過程をいい，同化とはエネルギーを 用いて必要な有機物を合成する過程をいう。しかし，代謝 の流れの中からどの部分を切り取るかという点においては, やはり恣意的であり，切り方を変えると異化と同化が反転 してしまう。別の分類もある。エネルギーの生産・消費に かかわらず生命維持に不可欠な代謝を一次代謝, 生命維持 に直接関与しないと考えられる代謝を二次代謝とする考え 方である。この定義で膨大な数の代謝物をうまく分類でき れば良いが，現実にはこれもなかなか難しい。ただ，この 分類が非常に使いやすいため，いまでは使用実績ゆえに簡 単に否定できない状況に陥っている。とはいえ，タイトル に植物の二次代謝という用語を使っている以上，ある程度 はこの概念に従うことにする。 二次代謝系で出現する化合 物群を二次代謝物と呼び，現在では polyketides, terpenoids, alkaloids phenylpropanoids をはじめとして種々の抗生物質や 複合経路から生合成される 20 万種を超える多様な化合物群 を包含する．では植物は，何故これらの化合物群を作るの か. 多くの報告は, 種々の二次代謝物を生態相関物質とし て，あるいは薬剤のリードとして記述するが，何故作るの かという問いに答えることはほとんどない。1989年に Williams らが，正面からこの問題を論じているが，やはり 
代謝物を生き残りのための適応度の指標として捉えている 8). しかしながらこれらの説明には，二次代謝産物の生合 成を，生合成された後に獲得した機能で説明するという時 間的な問題が存在する。 ある代謝物 X が存在する理由を, $\mathrm{X}$ が作られた後で獲得した機能に求めるべきではない，そ れは科学がその歴史の中で追放してきた悪しき目的論では なかったのか。

さて，私は同化と異化，一次代謝と二次代謝という分類 を否定し，かつ現在認められている代謝物の機能による説 明まで否定してしまった。こうした代謝物の分類と存在意 義の説明を否定したうえで，いわゆる二次代謝物をどのよ うに捉えるべきか。植物は光合成を行う独立栄養生物であ る. 植物は太陽光の中で $480-550 \mathrm{~nm}$ 以外の光を吸収して光 化学系を駆動し, ATP と $\mathrm{NADPH}_{2}^{+}$と $\mathrm{O}_{2}$ を生産する。 $\mathrm{O}_{2}$ は 気孔から捨てられ，ATP と $\mathrm{NADPH}_{2}^{+}$はカルビンサイクルで $\mathrm{CO}_{2}$ の還元に用いられ糖の生産に用いられる。ところが， $\mathrm{CO}_{2}$ 固定の段階で働くRubisco はオキシゲナーゼ活性をも つため，通常の条件でも約 $30 \%$ ，水不足や強光など厳しい 条件下においては $75 \%$ を超える同化糖を光呼吸系で再酸化 する ${ }^{9)}$. こうした損失を除いた残余分から膨大な量の phenylpropanoids, isoprenoids, polysaccharides な゙の代謝物が生 産されるだけでなく，生産物の大部分は落葉，枯死，揮発 性有機物などの形で廃棄される。この現象から植物の生活 が膨大な浪費のうえに成り立っていると見ることは可能だ が，実態はそうではない，ATP， NAD $(\mathrm{P}) \mathrm{H}_{2}^{+}$，糖がいかに有 用な物質であったとしても，生産に見合う適切な消費を伴 わない場合，それらは系のバランスを壊し生産系の崩壊を もたらしてしまう. 光化学系による ATP と $\mathrm{NADPH}_{2}^{+}$の生産 のみが続けば，光化学系では電子の流れが滞り ${ }^{1} \mathrm{O}_{2}$ や $\mathrm{O}_{2}^{-}$ が生成し，植物は枯死せざるを得ない，光化学系で生産さ れる ATP と $\mathrm{NADPH}_{2}^{+}$は速やかに消費され，ADP+Pi と $\mathrm{NADP}^{+}$の形で系に戻されなければならない，光化学系に続 いてカルビンサイクルが駆動して $\mathrm{CO}_{2}$, ATP と $\mathrm{NADPH}_{2}^{+}$か ら糖の生産が起こるが，この系では光化学系で作られた ATP と $\mathrm{NADPH}_{2}^{+}$を消費しきれないだけでなく, 生産された 糖による浸透圧の上昇が新たな問題となる。私は，カルビ ンサイクルの生産物を3-ホスホグリセリン酸（3-PGA）と 考えているが，植物細胞の生き残りにはこの 3-PGA を核と して ATP と $\mathrm{NADPH}_{2}^{+}$の消費のための系の構築が不可欠て あったに違いない，共生において，共生微生物は宿主と重 複する代謝系を失う場合が多い。葉緑体内には，デンプン 合成, MEP/DOXP 経路によるテルペン合成, 芳香族アミノ 酸合成, 脂肪酸合成など大量の ATP と $\mathrm{NADPH}_{2}^{+}$の消費と 伴う生合成系が存在する，植物細胞の原形質中にもデンプ ン合成系，メバロン酸経由のテルペン合成系，脂肪酸の伸 長反応系が存在するにもかかわらず，葉緑体がこれらの代 謝系を維持してきたのは, 迅速な ATP と $\mathrm{NADPH}_{2}^{+}$還流系
の重要性を示しているのではないか.さらに, 葉緑体内で の一過性のデンプン合成は昼間の急激な浸透圧上昇の回避 に有効であったに違いない，MEP/DOXP 経路によるイソプ レンの生合成と放出も 3-PGA の消費を伴うATP と $\mathrm{NADPH}_{2}^{+}$還流系として説明できる. 芳香族アミノ酸の生合 成は， lignin 生合成につながる経路であり，この系も膨大な 量の 3-PGA，ATP と $\mathrm{NADPH}_{2}^{+}$消費系として説明できる．さ らに葉緑体で処理しきれずに細胞質へ運ばれた糖は，一部 は蜜としてそのまま分泌されるだけでなく, 浸透圧に影響 しないデンプンやセルロースなどの多糖類へと変換される. 我々は，従属栄養生物として「もっとエネルギーを」とい う視点から自然界を解釈してきた。この意識が，共生を通 して葉緑体という膨大な生産力を持つ細胞小器官を獲得し た植物の「過剩生産という重荷」への気付きを妨げてきた のでないだろうか. (Hidden burden hypothesis）このように 考えると，シキミ酸系路に組み込まれた lignin 合成，糖の 代謝系に組み込まれた多糖類の合成, 脂肪酸合成系に組み 込まれたトリグリセリドの合成，あるいはイソプレノイド 生合成系に組込まれたイソプレンやモノテルペン合成など を，作られることに意義がある代謝物として合理的に意義 付けることが可能になる，さらに，「ある代謝の流れの中 で，生物が代謝物 X を生産する意義をどこに求めるか？」 という問いを提起していたが，通常は目的論的にならない ように用心しながらも，代謝物の機能に従って説明される ことが多い，例えば，植物のアミロースやアミロペクチン などは貯蔵多糖，セルロースやへミセルロースなどは構造 多糖として記述されるし, lignin 屯構造維持のためのポリ マーとして記述される。これらの説明は直感的には理解し やすいが，代謝の起源をも考えたとき，作られるのが先で あって機能獲得はその次のプロセスである．Xが生産され る理由は，Xが作られる過程の中に求めるべきであろう. 例えば，多糖類は 3-PGA，ATP と $\mathrm{NADPH}_{2}^{+}$を消費するとと もに細胞内浸透圧を維持するために作らざるを得なかった ポリマーであり, 生合成が細胞内で起こり, 後にその分解 系が成立したデンプン，イヌリン，マンナンなどが貯蔵多 糖としての機能を獲得し, 生合成が細胞外で起こったセル ロースやヘミセルロースなどは，細胞壁成分としての機能 を獲得したと，多細胞化し陸上へ進出した植物は，過剩な ATP, $\mathrm{NAD}(\mathrm{P}) \mathrm{H}_{2}^{+}$と糖を生理的に不活性で水に不溶な化合 物へ，あるいは体外に廃棄できる化合物へと変換するシス テムが不可欠だったに違いない。「ある事柄を説明するため には，必要以上に多くの仮定を持ち込むべきでない」とす るオッカムの剃刀（思考節約の法則）が真偽の判定則にな らないとはいえ, 個々の代謝物の活性に生合成の意義を求 める説明より，「過剩生産の重荷」という 1 つの概念の導入 で，すべての二次代謝物の意義を説明できるとすれば，後 者の説明の方が合理的ではないだろうか. 


\section{Oxidative Metabolic Burst Hypothesis}

上の議論において，光合成に伴って生産される $\mathrm{O}_{2}$ の問題 にはあえて触れなかったが，植物にとって $\mathrm{O}_{2}$ の問題は無視 できない大きな問題である．もちろん $\mathrm{O}_{2}$ に由来する毒性に ついては，活性酸素の生成と消去に焦点を当てた膨大な量 の研究が存在する ${ }^{10)}$ 。しかしながら，植物細胞ではそもそ も $\mathrm{O}_{2}$ 分圧が高いため, $\mathrm{O}_{2}$ そのものの消去が必要であると する視点はなかったように思う。例えば，光呼吸を光合成 で得られた糖とエネルギーを無駄に捨てる無益回路あるい はグリコール酸のサルベージ回路などとして考えるのでは なく，光合成で生産された過剩の糖とエネルギーを消去す ると同時に， $\mathrm{O}_{2}$ の消去を行っている系と考えてみてはどう だろう。「 $\mathrm{O}_{2}$ も消去すべき過剩生産物である」とする新た な視点を導入すると，単に $\cdot \mathrm{O}_{2}^{-}$の処理系として理解されて きた SOD-catalase 系や SOD-peroxidase 系なども， Fig. 4 に 示すように， $\mathrm{O}_{2}$ の消去という側面から再評価できると考え る。さらに, Fig. 5 に示すように, lignin 生合成は理想的と も言える 3-PGA, ATP, $\mathrm{NADPH}_{2}^{+}$と $\mathrm{O}_{2}$ の消費系として捉え ることができる．近年 R. A. Berner は， 6 億年の大気中 $\mathrm{O}_{2}$
濃度の変遷を計算するプログラムによる計算結果から，動 物の絶滅と進化が $\mathrm{O}_{2}$ 濃度の急減に伴って起こることを示し た ${ }^{11)}$ 。 Berner は言及していないが，植物の絶滅と進化は， 大気中の $\mathrm{O}_{2}$ 濃度の上昇あるいは $\mathrm{CO}_{2}$ 濃度の減少する時期 に起こっているようにみえる，私見だが， $\mathrm{O}_{2}$ 消去を重視す る立場からみると，始祖真核細胞による原ミトコンドリア 獲得においても, 原ミトコンドリアの $\mathrm{O}_{2}$ を消去する役割に 注目すべきだと考える. 原ミトコンドリアを細胞内へ浸透 してくる $\mathrm{O}_{2}$ を消去する共生生物として捉える立場むあるの

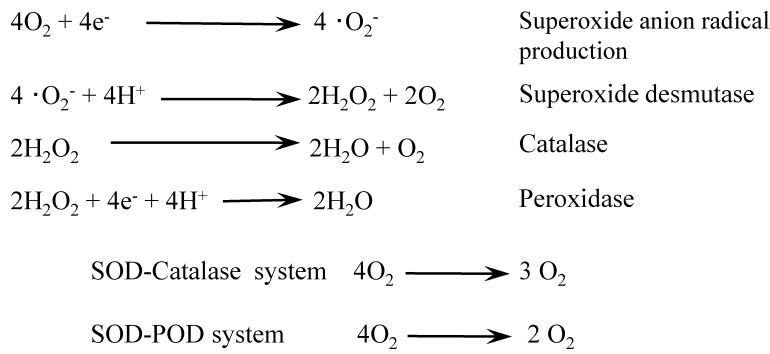

Fig. 4. Oxygen molecules are also quenched in such the active oxygen quenching systems as SOD-catalase and SOD-peroxidase systems.

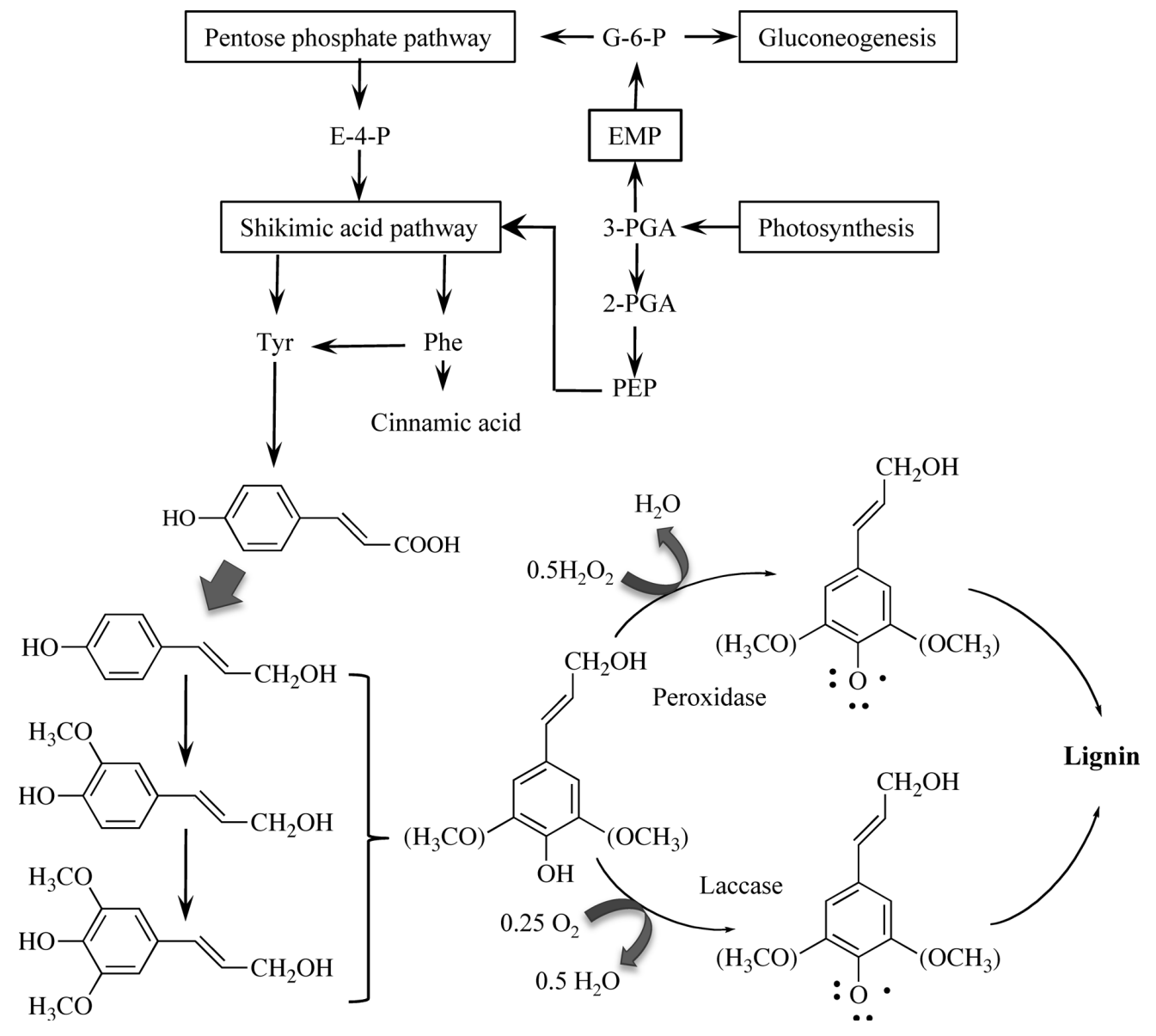

Fig. 5. Excess ATP, $\mathrm{NADPH}_{2}^{+}, 3-\mathrm{PGA}$ and $\mathrm{O}_{2}$ are quenched in lignin biosynthesis. 
ではないか. 現在, ミトコンドリアは「細胞における発電 所である」と説明するのが通例であるが, 細胞核周囲の嫌 気状態を担保している細胞小器官であるとする考え方も成 立するであろう。また種々の代謝系において, 代謝系の爆 発的多様化（Oxidative metabolic burst）は，酸化酵素とりわ け CYP のような酸素添加酵素による酸化を起点として始 まっている ${ }^{12)}$. これらの反応も $\mathrm{O}_{2}$ の消去反応と見ること ができる。これは地球大気中の $\mathrm{O}_{2}$ 濃度の上昇に伴い, 多様 な $\mathrm{O}_{2}$ 消去系が動き始めたことを意味する．CYP 遺伝子は ヒトに 57 種が存在しているのに対して, シロイヌナズナで 246 種, イネで 356 種と際だって多く, 植物ゲノム遺伝子 の約 $1 \%$ をしめる酵素ファミリーである ${ }^{13)}$ 。この事実を, CYP は多種多様な二次代謝産物を作るために発達した酵素 群と見るのではなく, $\mathrm{O}_{2}$ 分圧の高い植物細胞において $\mathrm{O}_{2}$ 消去の必然性から発達した醳素群であり, その結果いわゆ る二次代謝が高度に発達したと考えるべきであろう。また， CYP は通常の酵素に比へ， $\mathrm{O}_{2}$ 受容体となる基質に対する特 異性が甘い特徴がある。しかし， $\mathrm{O}_{2}$ という基質（毒物）を 活性化してもう一つの基質に結合させることが CYP に求め られた機能であるなら，あう一つの基質に対する基質特異 性は低い方が好ましいであろう。どうやら，酵素には厳密 な基質特異性と反応特異性を高めていったいわゆる普通の 酵素群之, 解毒酵素に代表されるように一方の基質につい てゆるい基質特異性の獲得に向かって進化してきた消去・ 廃棄の局面で働く䤉素群があるように思われる。 Oxidative metabolic burst に伴って生成した膨大な種類の代謝物の中か ら，その時代に機能していたレセプターあるいはオーファ ンレセプターと親和性をもち，かつ適切な濃度変化を示す 可能性を持つ化合物が，次の時代の生理活性物質として選 拔されていったとするのが論理的であろう.

\section{4. 将来の農薬開発の方向}

従来の農薬開発においては，微量で生理活性の高い化合 物（Noisy minority）をリードとした開発が行われてきた. しかし上述したように，植物は膨大な量の糖， $\mathrm{NAD}(\mathrm{P}) \mathrm{H}_{2}^{+}$ とATP とともに，細胞内で生成した $\mathrm{O}_{2}$ を消去せざるを得 ない生物である。従って，多種の生理活性のない化合物 （Silent majority）が作られる必然性が生じる。こうした観点 に立てば，いわゆる無益回路と呼ばれている経路は除草剂 創製のターゲットとして考えるべきであろう。また， lignin， セルロース，スターチなどの Silent majority にも，作られる
べき必然性が存在する．したがって，これら化合物群の生 合成系も，除草剂開発のターゲットになり得ると考える. 一方，このような Silent majority の生合成系を弱く阻害する ことで，目的とする他の物質の生産系へと代謝の流れを振 り向ける試みはできないだろうか。年 6 億トンにも上るイ ソプレンへの流れを, 多糖あるいはトリグリセリド生合成 ヘシフトさせることなど, 夢のある研究テーマが生まれて くるように思われる。

\section{引 用 文 献}

1) G. Michal (ed.): "Biochemical pathways: An Atlas of Biochemistry and Molecular Biology," A John \& Wiley \& Sons, New York USA, pp. 27-31, 1999.

2）小林哲夫：蛋白質 核酸 酵素，38, 1575-1578 (1993).

3) N. Kresge, R. D. Simoni and R. L. Hill: J. Biol. Chem. 280, e3. (2005).

4) A. H. Romano and T. Conway: Res. Microbiol. 147, 448-455 (1996).

5) N. Kresge, R. D. Simoni and R. L. Hill: J. Biol. Chem. 280, e18 (2005).

6) T. Kanao, M. Kawamura, T. Fukui, H. Atomi and T. Imanaka: Eur. J. Biochem. 269, 1926-1931 (2002).

7) M. Kates, D. J. Kushner and A. T. Matheson, "The Biochemistry of Archaea (New Comprehensive Biochemistry)," pp. 1-24, Elsevier Science, Amsterdam.

8) D. H. Williams, M. J. Stone, P. R. Hauck and S. K. Rahman: J. Nat. Prod. 52, 1189-1208 (1989).

9) Hans-Walter Heldt (Ryuji Kani 訳): "Pflanzenbiochemie," Splinger, Tokyo, pp. 170-171, 1999.

10）中野 稔, 大柳善彦, 浅田浩二編：“活性酸素一生物での 生成・消去・作用の分子機構”, 共立出版 (1989).

11) R. A. Berner, Geocarbsulf: Geochim. Cosmochim. Acta, 70, 5653-5664 (2006).

12) M. Mizutani and D. Ohta: Annu. Rev. Plant Biol. 61, 291-315 (2010).

13）水谷正治：“蛋白質 核酸 酵素” 52, 1454-1465 (2007)

\section{略 歴}

吉川 博道（よしかわ ひろみち）

生年月日：昭和 23 年 1 月 27 日

最終学歴: 九州大学大学院農学研究科博士後期課程

専門：植物科学, 農薬科学, 環境科学

趣味：読書, ソフトボール, 神社・仏閣巡り 